\title{
Effect of transforaminal anterior epidural steroid injection on neuropathic pain, quality of sleep and life
}

\author{
Transforaminal anterior epidural steroid enjeksiyonunun \\ nöropatik ă̆gr, uyku ve yaşam kalitesi ïzerine etkisi
}

Sinem SARI, ${ }^{1}$ Osman Nuri AYDIN, ${ }^{2}$ Gülsüm GÜLESER, 1 İmran KURT, ${ }^{3}$ Alparslan TURAN ${ }^{4}$

\begin{abstract}
20
Summary

Objectives: Transforaminal anterior steroid injections are frequently used for low back pain. In the current study, It was aimed to investigate the effects of transforaminal anterior epidural steroid injection (TAESI) in patients with low back pain in regards to quality of life and sleep, and neuropathic pain.

Methods: Ethics committee approval and patient consent were obtained. Patients with low back pain scheduled to receive transforaminal epidural steroid injections between October 2011 and October 2012 were included into the study. Pittsburgh Sleep Quality Index (PSQI), Short form 12 (SF 12), DN4 tests and Visual Analog Scale Score (VAS) were measured prior to procedure and three months later. All the tests were compared with baseline evaluations prior to injections.

Results: One hundred and two (female/male: 52/50) patients with a mean age of 53.3 \pm 1.4 were included. Primary diagnoses were lumbar disc herniation in eighty-seven patients, spinal stenosis in seven and failed back surgery syndrome in eight patients. Statistically significant improvement was seen in the total VAS, DN4 and PSQI scores $(\mathrm{p}=0.0001)$ of the patients at the third month follow-up. Sleep duration $(p=0.0001)$, habitual sleep efficiency $(p=0.0001)$, subjective sleep quality $(p=0.003)$, sleep latency $(p=0.014)$, sleep disturbances $(p<0.001)$, sleep medication use $(p=0.003)$, and day time dysfunction $(p=0.015)$ showed a significant decrease in sub-components. There was no significant difference in SF 12 quality of life.

Conclusion: It was determined in the study that transforaminal epidural steroid injection provided a substantial improvement in patients' pain and neuropathic pain and quality of sleep, but had no effect on the quality of life.

Key words: Neuropathic pain; transforaminal anterior epidural steroid injection; quality of life; quality of sleep.
\end{abstract}

\section{Özet}

Amaç: Bu çalışmada bel ağrısı dolayıst ile transforaminal anterior epidural steroid injeksiyonu (TAESİ) uygulanan hastalarda yapılan girişimin, yaşam, uyku kalitesi ve nöropatik ağrı üzerine üzerine etkilerinin araştırılması amaçlanmıştır.

Gereç ve Yöntem: Çalı̧̧mamıza Adnan Menderes Üniversitesi Tip Fakültesi Etik Kurul izni ve hasta onamı alındıktan sonra Ekim 2011 Ekim 2012 taribleri arasında Algoloji Bilim Dalı Polikliniğine bel ağrısı şikayeti ile başvuran ve transforaminal anterior epidural steroid enjeksiyonu yapılmış hastalar dabil edildi. İşlem öncesi ve sonrası hastalara Pittsburgh Uyku Kalitesi Ölçeği (PSQI), Kısa form 12 (SF 12) ve DN4 testi uygulandı ve Visual Analog Skala (VAS) Skoru bakıldr.

Bulgular: Çalı̧maya 102 (Kadın/Erkek: 52/50) hasta dâbil edildi. Hastaların yaş ortalaması $53.29 \pm 1.39$ idi. Seksen yedi hasta lomber disk hernisi, yedi hasta spinalstenoz, sekiz hastanın başarısız bel cerrabisi tanısı mevcuttu. Hastaların VAS, DN4 ve PSQI toplam değerlerinde istatistiksel olarak anlamlı düzelme görüldü $(p=0.0001)$. Uyku kalitesi ölçeğinin uyku süresi $(p=0.0001)$ ve alş̧lmış uyku etkinliği ( $p=0.0001)$ alt komponentlerinde çok anlaml olmak üzere, subjektif uyku kalitesi $(p=0.003)$, uykuya dalma süresi $(p=0.014), u y k u$ bozuklukları $(p<0.001)$, uyku ilacı kullanımı $(p=0.003)$ ve gündüz işlevsellik kaybı $(p=0.015)$ alt komponentlerinde anlamlı düzelme görüldü. Yaşam kalitesinde anlaml farklilik tespit edilmedi.

Sonuç: Çalışmamızda bel ă̆rısı dolayısı ile yapılan transforaminal anterior epidural steroid uygulamasının, bastaların ağrı, nöropatik ağrı ve uyku kalitesinde anlamlı ölçüde iyileşme sağladığın fakat yaşam kalitesi üzerine etkili olmadı̆̆ın tespit ettik.

Anahtar sözcükler: Nöropatik ağrı; tranforaminal anterior epidural steroid enjeksiyonu; yaşam kalitesi; uyku kalitesi.

\footnotetext{
'Department of Anesthesiology and Reanimation, Adnan Menderes University Faculty of Medicine, Aydin, Turkey;

2Department of Algology, Adnan Menderes University Faculty of Medicine, Aydin, Turkey;

${ }^{3}$ Department of Statistic, Adnan Menderes University Faculty of Medicine, Aydin, Turkey;

${ }^{4}$ Department of Outcomes Research, Cleveland Clinic, Ohio, USA

'Adnan Menderes Üniversitesi Tıp Fakültesi, Anesteziyoloji ve Reanimasyon Anabilim Dalı, Aydın;

${ }^{2}$ Adnan Menderes Üniversitesi Tıp Fakültesi, Algologi Bilim Dalı, Aydın;

${ }^{3}$ Adnan Menderes Üniversitesi Tıp Fakültesi, İstatistik Anabilim Dalı, Aydın;

${ }^{4}$ Cleveland Klinik, Klinik Araştırmalar Departmanı, Ohio, ABD
}

Submitted (Başvuru tarihi) 08.10.2013 Accepted after revision (Düzeltme sonrası kabul tarihi) 21.07.2014

Correspondence (iletişim): Dr. Sinem Sarı. Adnan Menderes Üniversitesi Tip Fakültesi, Anesteziyoloji ve Reanimasyon Anabilim Dalı, Aydın, Turkey.

Tel: +90 - 256 - 444 12 56 / 2115 e-mail (e-posta): sarisinem@yahoo.com 


\section{Introduction}

Low back pain is a health problem that varies according to cause and population, exhibiting a prevalence of $10 \%-20 \%$ annually and of $50 \%-80 \%$ over a lifetime. ${ }^{[1,2]}$ It is reported that more than half of patients complaining of low back pain experience diminishment in their working lives and daily activities and in Europe, this is the second most frequent cause of sick leaves. This places a great burden on both the health system and the economy. ${ }^{[3,4]}$ A great majority of patients presenting with low back pain complaints benefit from conservative and noninvasive modes of treatment that include bed rest, oral medications, corsets and physical therapy but one-fourth of these patients are likely to reappear at the hospital within the same year due to a relapse of the condition.Ten percent of such patients become chronic cases and $10 \%-15 \%$ ultimately need surgery. ${ }^{[1,3,5-7]}$ Of patients undergoing surgery, $20 \%$ go through another surgical procedure due to continued pain. ${ }^{[8]}$ This situation has led patients to consider more effective and minimally invasive treatment options.

Intervertebral disk herniation is the most frequent cause of lumbosacral radiculopathy. ${ }^{[9,10]}$ and the most prominent mechanism creating the pain is indicated to be the inflammation that impinges upon the nerve roots. ${ }^{[1]}$ The implementation of epidural steroid injections, a procedure to reduce inflammation that was first suggested by Robecchi and Capra in $1952,{ }^{[12]}$ is among the primary methods of treatment widely used today as minimally invasive therapy. ${ }^{[13]}$ Although there are different methods used in epidural steroid injections such as caudal, interlaminar, transforaminal injections, ${ }^{[14,15]}$ fluoroscopy-assisted transforaminal anterior epidural steroid injections (TAESI) are more commonly preferred because they can be guided directly into the targeted area and also make use of a lesser amount of medication. ${ }^{[6,16-20]}$

Pain that is not effectively treated leads to mood and sleep disorders, impedes patients' working and social lives and diminishes quality of life. It has therefore become an increasingly important issue in terms of public health. There are studies that have evaluated the direct effect of TAESI on pain. The literature however is lacking in studies that examine the effect of TAESI on other factors that influence patient satisfaction. The present study aimed at exploring the effects of TAESI on pain, quality of life and sleep quality, and on neuropathic pain.

\section{Materials and Methods}

After obtaining permission from the Adnan Menderes University Faculty of Medicine Board of Ethics and the written consent of patients, the study was conducted over the period October 2011-October 2012 with patients who had applied to the Algology Department Polyclinic with complaints of low back pain and had received TAESI. The research was of prospective design and was carried out with 102 patients over the age of 18 who were classified as ASA I-III. Patients must have failed previous medical therapy, exercise therapy, etc., prior to starting interventional pain management techniques.

Exclusion criteria for the study were accepted as: 1) Patients who displayed general contraindications for minimal invasive procedures such as coagulapathy, sepsis, or infection in the area of intervention; 2) $\mathrm{Pa}$ tients who displayed surgical indications of lumbar disk herniation; 3) Pregnancy; 4) Patients allergic to any of the substances to be used during the procedure; 5) Patients had prior TAESI.

\section{Protocol}

During the evaluation of the patients prior to the procedure, the patients were provided with information about VAS scores $(0=$ no pain, $10=$ severest pain) and the questionnaires, the Pittsburgh Sleep Quality Index (PSQI), Short Form 12 (SF-12) and the DN4 Test, and they were asked to fill out the questionnaires before undergoing the procedure. Vascular access was established in all the patients and a $0.9 \%$ isotonic sodium chloride solution was started for intravenous premedication with $0.02 \mathrm{mg} / \mathrm{kg}$ midazolam $+1 \mathrm{mcg} / \mathrm{kg}$ fentanyl. The patients were placed in a prone position on the fluoroscopy table and routinely monitored for heartbeat rate, blood pressure and oxygen saturation. The areas on the patient's body that were to undergo intervention were wiped with an iodine-based antiseptic solution and covered in line with sterilization protocol. All of the procedures were carried out under local anesthesia using C-arm fluoroscopic guidance. 
The TAESI procedure started by first placing the Carm scope in antero-posterior position to fix its level for the intervention. The scope was brought into an approximate 15-20-degree oblique position to obtain an image of the interverrtebral foramina at the level at which the intervention would take place. After the skin and subcutaneous region was infiltrated with $1 \% 1 \mathrm{ml}$ lidocaine, a $21 \mathrm{G} 100 \mathrm{~mm}$ stimulation needle (Stimuplex A 100, B Braun, Melsungen, Germany) was guided into the intervertebral foramen. When sufficient depth had been reached and it was decided from the frontal, anterior and lateral images that the point of the needle was in suitable position at the foramen, a $0.5-1 \mathrm{ml}$ contrast agent was injected to check whether there was typical anterior epidural spread. When the spread of the contrast was achieved, the image was verified with anterior-posterior and lateral projections. Subsequently, a mixture of an $80 \mathrm{mg}$ ampoule of triamcinolonacetonide (Sinokort A ampoule, $40 \mathrm{mg} / \mathrm{ml}$ ) and $3 \mathrm{~mL}$ of $0.5 \%$ bupivacaine was injected accompanied by negative aspiration. The total amount of triamcinolonacetonide to be utilized was fixed at $80 \mathrm{mg}, 4 \mathrm{ml}$ of the mixture to be injected if the procedure involved a single level, and $3 \mathrm{ml}$ of the mixture for each level if there was more than one level involved.

After the procedure, all of the patients were monitored in the recovery room for early signs of complication. The patients were then taken to their floors and monitored by the floor nurse for complications and VAS scores. None of the patients experienced any problems and therefore their prescriptions were drawn up and they were discharged with the request that they come back for a control visit at the end of 15 days.

\section{Measurements}

The patients' morphometric and demographic data (age, gender, weight and height), the duration of their symptoms and the history of previous surgeries, how many times the transforaminal epidural steroid injections were performed, at how many levels the procedure was performed and complication data, if any, were recorded prior to the procedure.

The patients' pain scores were evaluated on a $10 \mathrm{~cm}$. Visual Analogue Scale (VAS) ( $0=$ no pain; $10=$ sever -
Table 1. Baseline characteristics of the patients

\begin{tabular}{lcc}
\hline & n & Mean \pm SD \\
\hline Women/Men & $52 / 50$ & \\
Age (years) & & $53.29 \pm 11.3$ \\
Height (cm) & $167 \pm 8.9$ \\
Weight (kg) & & $75.5 \pm 12.6$ \\
\hline
\end{tabular}

Data are represented as mean \pm SD. SD: Standard deviation.

Table 2. Duration of patients' pain before the procedure

\begin{tabular}{lc} 
Duration of pain & Number of pat \\
\hline$<1$ month & 4 \\
$1-6$ months & 12 \\
$6-12$ months & 25 \\
$>12$ months & 61
\end{tabular}

est pain). Quality of life was assessed with the SF 12 , sleep quality with the PSQI, and neuropathic pain with the DN 4 questionnaires. The VAS, SF12 , PSQI and DN4 tests were implemented at the measurement parameter of the patients' third postoperative month. TAESI was evaluated on the basis of a comparison of these measurements with preprocedure values.

\section{Statistics}

Since the score data consisted of dependent variables, the Wicoxon Signed Rank test was utilized in the comparison and descriptive statistics were indicated with a median $\left(25^{\text {th }}-75^{\text {th }}\right.$ percentile); $\mathrm{p}<0.05$ was accepted as significant.

\section{Results}

A total of 137 patients were evaluated prior to the procedures. Of these patients, 104 were reached in the $3^{\text {rd }}$ month. Two of the patients did not agree to fill out the questionnaire again. Thus, the research was carried out with 102 patients.

The morphometric and demographic data for the patients can be seen in Table 1 . The period of time from the start of the pain to the time the patient presented at our polyclinic is seen in Table 2 .

Of the patients included in the research, the proce- 
Table 3. Patients' TAESI evaluation parameters

\begin{tabular}{|c|c|c|c|}
\hline & Preoperative & $3^{\text {rd }}$ Month postoperative & $\boldsymbol{p}$ \\
\hline & Mean \pm SD & Mean \pm SD & \\
\hline Visual analogue scale & $6.8 \pm 1.5$ & $3.7 \pm 2.1$ & $0.0001^{* *}$ \\
\hline Short form 12 & $29.6 \pm 3.5$ & $29.2 \pm 3.6$ & 0.28 \\
\hline $\mathrm{DN} 4^{* * *}$ & $58(56.9 \%)$ & $35(34.3 \%)$ & $0.0001^{* *}$ \\
\hline Pittsburgh sleep quality index & $13 \pm 4$ & $10.2 \pm 4.1$ & $0.0001^{* *}$ \\
\hline Subjective sleep quality & $1.9 \pm 0.8$ & $1.6 \pm 0.7$ & $0.003^{*}$ \\
\hline Sleep latency & $1.9 \pm 0.9$ & $1.6 \pm 0.9$ & $0.014^{*}$ \\
\hline Sleep duration & $2 \pm 0.9$ & $1.4 \pm 1$ & $0.0001^{* *}$ \\
\hline Habitual sleep efficiency & $1.8 \pm 1$ & $1.1 \pm 0.9$ & $0.0001^{* *}$ \\
\hline Sleep disturbances & $2.3 \pm 0.6$ & $1.9 \pm 0.7$ & $0.0002^{*}$ \\
\hline Use of sleeping medications & $1.2 \pm 1.4$ & $0.8 \pm 1.2$ & $0.030^{*}$ \\
\hline Daytime dysfunction & $2 \pm 0.9$ & $1.7 \pm 0.9$ & $0.015^{*}$ \\
\hline
\end{tabular}

Data are represented as mean $\pm \mathrm{SD}$, and percentage $(\%) .{ }^{*} \mathrm{p}<0.05 ;{ }^{* *} \mathrm{p}<0.0001 ;{ }^{* * *} \mathrm{DN} 4$ score are represented as numbers of patients who have score positive. SD: Standard deviation.

dure was performed on 87 patients with herniated discs, 7 patients with spinal stenosis and 8 patients who had previously undergone failed low back surgery.

The patients displayed statistically significant improvements in their total VAS, DN4 and PSQI scores $(\mathrm{p}=0.0001)$. It was seen that the improvements in the sub-components of sleep duration $(\mathrm{p}=0.0001)$ and habitual sleep efficiency $(\mathrm{p}=0.0001)$ on the sleep quality scale were strikingly significant; significant improvements were also seen in the other components of subjective sleep quality $(\mathrm{p}=0.003)$, sleep latency $(\mathrm{p}=0.014)$, sleep disturbances $(\mathrm{p}<0.001)$, use of sleeping medications $(\mathrm{p}=0.003)$, and daytime dysfunction $(p=0.015)$. No significant difference was found in quality of life (Table 3).

Patients had no major complication. Pain in the needle-inserted place were observed in two patients.

\section{Discussion}

The patients in the study exhibited statistically significant improvements in their third month VAS, neuropathic pain and sleep quality scores compared to their previous scores, but no difference was seen in the patients' quality of life.

There are many factors that determine the effective- ness of TAESI. The most important of these are the etiology and pathology of the low back pain experienced. While it is commonly known that TAESI is effective in the case of spinal stenosis and unsuccessful low back surgery etiology, ${ }^{[13,21-23]}$ it has been shown to be particularly more effective in discogenic low back pain. ${ }^{[13,24,25]}$ In the present study, $85 \%$ of the patients suffered from pain stemming from lumbar disc herniation while $15 \%$ had diagnoses of unsuccessful back surgery and spinal stenosis. Another factor that similarly determines the effectiveness of TAESI is the duration of pain patients experience before the procedure. While it has been found that the chance of success of TAESI is higher in the case of pain lasting for shorter periods, the effectiveness of the procedure in patients who have been experiencing chronic pain for longer periods is controversial. ${ }^{[26]}$ In earlier publications, cases not cured within 3-6 months were accepted as chronic low back pain whereas the more recent literature has brought this period down to 7-8 weeks. In the present study, $60 \%$ of the patients had been experiencing pain for more than one year prior to the procedure. Despite this, however, a statistically significant improvement was observed in our patients' VAS scores.

Today, chronic lumbar radicular pain is the most commonly experienced neuropathic pain syndrome. The mechanism of chronic low back pain is charac- 
terized by a combination of neuropathic and nociceptive mechanisms. ${ }^{[27]}$ There are studies that show that patients with chronic low back pain experience a reduction of the neuropathic component of their pain after the use of epidural steroids. ${ }^{[27]}$ In some studies, a $70 \%$ effectiveness of the procedure has been reported in patients who have been experiencing symptoms for less than six months but this success rate has been shown to drop to the $50 \%$ level in patients with symptoms lasting for one year and more. [5,7,27] Although more than half of the patients in the present study had been experiencing pain for more than one year, a statistically significant improvement was observed in their neuropathic pain scores.

It was also observed in the research that the patients' quality of life before the procedure was diminished but it was seen that there was no pronounced improvement in this state following the procedure. The most important reasons for this may have been that there was no marked improvement in pain scores and also that these patients had secondary conditions or were exposed to factors besides pain that were affecting their quality of life. Studies show that factors such as depression, dissatisfaction with work, obesity or smoking can frequently accompany low back pain and become elements that affect quality of life. ${ }^{[2]}$ The present study did not include plans or arrangements for research or treatment of these outside factors.

Insomnia is clinically defined as a sleep disorder lasting for more than one month that involves an inability to obtain restful sleep and affects the daytime functional capacities of an individual. This condition may appear as a primary disorder or it may accompany some other medical disorder and/or psychiatric condition. The prevalence of insomnia among the patient population experiencing chronic pain is estimated to be around $50 \%-80 \%$. Thus, chronic pain and sleep problems need to be treated together. ${ }^{[28,29]}$ There is no study in the literature on how TAESI is associated with sleep quality but the effect of TAESI should be compared with the effects of other methods of low back pain treatment. Study results in the literature are similar to the results of the present study in that they indicate that physical therapy increases the quality of sleep and reduces insomnia. ${ }^{[30]}$
To conclude, the present research found that that implementation of transforaminal anterior epidural steroid injections for low back pain was successful in achieving a significant degree of improvement in the back pain and neuropathic pain patients were experiencing as well as in their quality of sleep but that they were not effective in improving quality of life.

\section{Conflict-of-interest issues regarding the author- ship or article: None declared.}

\section{Peer-rewiew: Externally peer-reviewed.}

\section{References}

1. Beaudet N, Courteau J, Sarret P, Vanasse A. Prevalence of claims-based recurrent low back pain in a Canadian population: a secondary analysis of an administrative database. BMC Musculoskelet Disord 2013;14:151. CrossRef

2. McCormick Z, Plastaras C. Lumbosacral transforaminal epidural steroid injections are equally effective for treatment of lumbosacral radicular pain in the obese compared to nonobese population: a pilot study. J Back Musculoskelet Rehabil 2013;26(2):183-8.

3. Gupta S, Gupta M, Nath S, Hess GM. Survey of European pain medicine practice. Pain Physician 2012;15(6):E983-94.

4. Wilkinson IM, Cohen SP. Epidural steroid injections. Curr Pain Headache Rep 2012;16(1):50-9. CrossRef

5. Vad VB, Bhat AL, Lutz GE, Cammisa F. Transforaminal epidural steroid injections in lumbosacral radiculopathy: a prospective randomized study. Spine (Phila Pa 1976) 2002;27(1):11-6.

6. Kawu AA. Epidural steroid injection in patients with lumbosacral radiculopathy in Abuja, Nigeria. J Neurosci Rural Pract 2012;3(2):121-5. CrossRef

7. Roy C, Chatterjee N, Patro SN, Chakraborty A, Vijay Kumar GR, Sengupta R. The efficacy of transforaminal epidural steroid injections in lumbosacral radiculopathy. Neurol India 2011;59(5):685-9. CrossRef

8. Gasiński P, Radek M, Jóźwiak J, Łyczak P. Peridural fibrosis in lumbar disc surgery--pathogenesis, clinical problems and prophylactic attempts. [Article in Polish] Neurol Neurochir Pol 2000;34(5):983-93. [Abstract]

9. Kang SS, Hwang BM, Son HJ, Cheong IY, Lee SJ, Lee SH, et al. The dosages of corticosteroid in transforaminal epidural steroid injections for lumbar radicular pain due to a herniated disc. Pain Physician 2011;14(4):361-70.

10. Lee JW, Kim SH, Choi JY, Yeom JS, Kim KJ, Chung SK, et al. Transforaminal epidural steroid injection for lumbosacral radiculopathy: preganglionic versus conventional approach. Korean J Radiol 2006;7(2):139-44. CrossRef

11. Quraishi NA. Transforaminal injection of corticosteroids for lumbar radiculopathy: systematic review and meta-analysis. Eur Spine J 2012;21(2):214-9. CrossRef

12. Lee JH, Moon J, Lee SH. Comparison of effectiveness according to different approaches of epidural steroid injection in lumbosacral herniated disk and spinal stenosis. J Back Musculoskelet Rehabil 2009;22(2):83-9.

13. Benyamin RM, Manchikanti L, Parr AT, Diwan S, Singh V, Falco FJ, et al. The effectiveness of lumbar interlaminar epidural injections in managing chronic low back and lower extremity 
pain. Pain Physician 2012;15(4):E363-404.

14. Parr AT, Diwan S, Abdi S. Lumbar interlaminar epidural injections in managing chronic low back and lower extremity pain: a systematic review. Pain Physician 2009;12(1):163-88.

15. Ackerman WE 3rd, Ahmad M. The efficacy of lumbar epidural steroid injections in patients with lumbar disc herniations. Anesth Analg 2007;104(5):1217-22. CrossRef

16. Landa J, Kim Y. Outcomes of interlaminar and transforminal spinal injections. Bull NYU Hosp Jt Dis 2012;70(1):6-10.

17. Çetin MF, Karaman $H$, Ölmez Kavak G, Tüfek A, Baysal Yildirim Z. Efficacy of transforaminal lumbar epidural steroid injections in patients with lumbar radiculopathy. Agri 2012;24(2):77-84. CrossRef

18. Rho ME, Tang CT. The efficacy of lumbar epidural steroid injections: transforaminal, interlaminar, and caudal approaches. Phys Med Rehabil Clin N Am 2011;22(1):139-48. CrossRef

19. Roberts ST, Willick SE, Rho ME, Rittenberg JD. Efficacy of lumbosacral transforaminal epidural steroid injections: a systematic review. PM R 2009;1(7):657-68. CrossRef

20. Buenaventura RM, Datta S, Abdi S, Smith HS. Systematic review of therapeutic lumbar transforaminal epidural steroid injections. Pain Physician 2009;12(1):233-51.

21. Cooper G, Lutz GE, Boachie-Adjei O, Lin J. Effectiveness of transforaminal epidural steroid injections in patients with degenerative lumbar scoliotic stenosis and radiculopathy. Pain Physician 2004;7(3):311-7.

22. Park $\mathrm{CH}$, Lee SH. Effect of RelativelnjectatePressures on theEfficacy of LumbarTransforaminalEpiduralSteroidInjection in PatientswithLumbarForaminalStenosis. PainPract
2013 Apr 16.

23. Atım A, Deniz S, Kılıçkaya O, Orhan ME, Purtuloğlu T, Kurt E. Assessment of the effectiveness of lumbar transforaminal epidural steroid injection for low back pain. Agri 2011;23(3):114-8. CrossRef

24. Benny B, Azari P. The efficacy of lumbosacral transforaminal epidural steroid injections: a comprehensive literature review. J Back Musculoskelet Rehabil 2011;24(2):67-76.

25. Lee JW, Choi SW, Park SH, Lee GY, Kang HS. MR-based outcome predictors of lumbar transforaminal epidural steroid injection for lumbar radiculopathy caused by herniated intervertebral disc. Eur Radiol 2013;23(1):205-11. CrossRef

26. Manson NA, McKeon MD, Abraham EP. Transforaminal epidural steroid injections prevent the need for surgery in patients with sciatica secondary to lumbar disc herniation: a retrospective case series. Can J Surg 2013;56(2):89-96. CrossRef

27. Rados I, Sakic Zdravcevic K, Hrgovic Z. painDETECT questionnaire and lumbar epidural steroid injection for chronic radiculopathy. Eur Neurol 2013;69(1):27-32. CrossRef

28. Purushothaman B1, Singh A, Lingutla K, Bhatia C, Pollock R, Krishna M. Prevalence of insomnia in patients with chronic back pain. J Orthop Surg (Hong Kong) 2013;21(1):68-70.

29. Tang NK, Wright KJ, Salkovskis PM. Prevalence and correlates of clinical insomnia co-occurring with chronic back pain. J Sleep Res 2007;16(1):85-95. CrossRef

30. Eadie J, van de Water AT, Lonsdale C, Tully MA, van Mechelen W, Boreham CA, et al. Physiotherapy for sleep disturbance in people with chronic low back pain: results of a feasibility randomized controlled trial. Arch Phys Med Rehabil 2013;94(11):2083-92. CrossRef 